University of Tulsa College of Law

TU Law Digital Commons

Articles, Chapters in Books and Other Contributions to Scholarly Works

2001

\title{
Copyright Law and Archival Research
}

Robert Spoo

Follow this and additional works at: http://digitalcommons.law.utulsa.edu/fac_pub

Part of the Intellectual Property Commons

This article was published in 24 J. Mod Lit. 205-12 (2000/2001) by Indiana University Press.

\section{Recommended Citation}

24 J. Mod Lit. 205-12 (2000/2001).

This Article is brought to you for free and open access by TU Law Digital Commons. It has been accepted for inclusion in Articles, Chapters in Books and Other Contributions to Scholarly Works by an authorized administrator of TU Law Digital Commons. For more information, please contact daniel-bell@utulsa.edu. 


\title{
Copyright Law and Archival Research
}

\author{
Robert Spoo \\ New York, New York
}

Scholars of modern literature who are interested in pursuing archival research may be interested to discover that there are obstacles which they must overcome. Most archival projects divide into two phases or desiderata: access and publication. Scholars first seek access to the contents of libraries and then, typically, plan to publish the results of their research. Both of these activities involve a certain amount of copying; and copying, for Modernist scholars, almost always raises the spectre of copyright prohibitions. Inasmuch as a copyright is the exclusive right of somebody else to reproduce, adapt, distribute, publicly perform, and publicly display a given work,' it can raise barriers to scholarship.

Copyright is not the only obstacle encountered by the archive-going scholar. Contract law also plays a role, particularly in the matter of access, but also in that of copying. Donors and sellers of manuscripts often place restrictions upon a library's use of the materials which it acquires. These transferors, whether the copyright owners or not, can ensure by contract that certain documents will remain sealed for a specified number of years, that documents will be shown only under certain conditions or to pre-approved persons, or that no photocopying (or other copying) will be made of documents. ${ }^{2}$

Such a contract, binding upon the library, can sometimes regulate copying more thoroughly even than a copyright. Copyright law, after all, is a blessedly porous mechanism that permits some copying under the fair use doctrine ${ }^{3}$ and under certain library exemptions, ${ }^{4}$ and that specifically excludes facts and ideas from protection. ${ }^{5}$ Contracts are bargains struck between parties in arm's-length negotiations, and they can be as stringent or flexible as the parties

\footnotetext{
' 17 U.S.C. $\$ 106$.

2 Libraries (such as the Beinecke at Yale) are more reluctant than they once were to enter into arrangements of this kind, but they have no choice but to honor agreements made in the past. Agreements that may limit access include selective restriction of access; restrictions "until death" of individuals; collections placed "on deposit"; and permanent loans. The constraining hand of the donor or seller can exercise ongoing control in each of these arrangements, and in others as well.

${ }^{3} 17$ U.S.C. $\S 107$.

${ }^{+}$Id. $\S 108$, permitting copying by libraries and archives for certain purposes, despite the copyright owner's exclusive rights.

${ }^{5}$ Id. $\$ 102(\mathrm{~b}):$ "In no case does copyright protection ... extend to any idea . . . or discovery, regardless of the form in which it is described, explained, illustrated, or embodied . . . ."
}

Robert Spoo, "Copyright Law and Archival Research," Journal of Modern Literature, XXIV, 2 (Winter 2000-2001), pp. 205-212. @Indiana University Press, 2001. 
wish. ${ }^{6}$ We have all encountered an archivist who mysteriously forbids the copying or quoting of material in circumstances that we feel certain would be exempted by copyright law. It is ironic to think that an unpublished work might enter the public domain after the expiration of its federal copyright term but remain sealed in an archive, and so inaccessible to the public, under state contract law.

Suppose that Professor A has overcome the first obstacle-archival access-and now wishes to publish the results of her research. She wants to quote modestly but representatively from published works and also from certain unpublished manuscripts and letters that she has encountered during her research. Professor A must first determine whether these works are protected by copyright and if so, whether she may reproduce any of the works' content in her published critical commentary. She will thus need information about two inversely related matters: the recent extension of copyrights in the United States and the United Kingdom and the doctrine of fair use.

In 1998, the United States Congress passed, and the President signed, the Sonny Bono Copyright Term Extension Act, ${ }^{7}$ which increased all future and existing American copyright terms by twenty years. Works first published in 1923 and afterwards were thereby prevented from entering the public domain until well into the next century. Similarly, in 1996, the United Kingdom implemented a European Union directive retroactively increasing copyright terms by twenty years." British and American copyright terms are therefore in rough harmony, despite some remaining disparities.

In the United States, works published between 1923 and 1978 now enjoy copyright protection for ninety-five years from the date of first publication (unless they entered the public domain earlier through the copyright owners' failure to renew copyright or through some other technicality). ${ }^{9}$ Works created on or after 1 January 1978 are copyrighted for the author's life plus seventy years, with protection beginning from the moment of creation, or "fixation," of the work." In Britain, copyrights endure for the same term, and certain userfriendly exemptions exist there for parties that relied on the public-domain status of works whose copyrights were extended or revived by the 1996 implementation."

\footnotetext{
${ }^{6}$ See id. $\$ 108(f):$ "Nothing in this section [concerning copyright exemptions for libraries and archives] ... in any way affects . . . any contractual obligations assumed at any time by the library or archives when it obtained a copy or phonorecord of a work in its collections."; cf. ProCD. Inc. v. Zeidenberg, 86 F.3d 1447 (7th Cir. 1996) (Easterbrook, J.), holding that a restriction placed on the use of uncopyrightable data as a result of a software shrinkwrap license was enforceable in contract and not preempted by federal copyright law, because both contracting parties had agreed to the restriction.

${ }^{7}$ Act of Oct. 27, 1998, Pub. L. No. 105-298, 112 Stat. 2827 (codified at 17 U.S.C. $\S 304(b)$ ).

"Copyright Designs and Patents Act, 1988 (Eng.) (the "CDPA"), as amended by Duration of Copyright and Rights in Performance Regulations, 1995 (Eng.) (the "Duration Regs.").

${ }^{9} 17$ U.S.C. $\$ 304$.

${ }^{10}$ Id. \$302(a). The present Copyright Act, unlike the previous 1909 Act, thus makes the moment of creation of the work, not the date of its publication, the trigger for statutory copyright.

${ }^{11}$ For example, a scholar or publisher who, in reliance upon a work's imminent copyright expiration under U.K. law, undertook to publish a public-domain edition of the work could proceed with that project upon certain conditions. Moreover, parties wishing to reproduce or adapt a work enjoying revived copyright may do so under a statutory compulsory license requiring only notice to the copyright owner and payment of a reasonable royalty. If the parties cannot agree upon a royalty, the Copyright Tribunal determines the license terms. Duration Regs. 23, 24, 25, 33, 34, \& 35. The Danis Rose edition of Ulysses, published in the Republic of Ireland and the U.K. in 1997, is an example of a project allegedly undertaken in reliance upon the public-domain status of a work later restored to copyright.
} 
I have suggested elsewhere that the fate of Modernism and the shape of the literary canon may be profoundly affected by this legislative foreshortening of the public domain-a development that, in my view, places works of the early twentieth century at a competitive disadvantage in the cultural and economic marketplace. ${ }^{12}$ Here, it is enough to observe that scholars of modern literature and arts need to be aware of these extended and revived copyrights in their dealings with libraries, publishers, authors, and authors' estates.

Copyrights in unpublished works have also been affected by the extension of copyright terms. In the United States, copyright in an unpublished work created before 1 January 1978 now endures for the life of the author plus seventy years. ${ }^{13}$ The Copyright Act further provides that in no case will copyright in a pre-1978 unpublished work expire before the end of 2002. And if the work is published before that date, it will enjoy a bonus extension of copyright through the end of the year $2047 .^{14}$

For example, if Professor A wishes to quote the text of an unpublished letter by Jack London, who died in 1916, she should know that it will remain in copyright until the end of 2002. Although the standard copyright term is the author's life plus seventy years, Congress, believing that this calculus would give too little protection to earlier authors' unpublished works, established 2002 as an equitable minimum terminus. After 2002, London's letter will enter the public domain in the United States, unless it is published before that date, in which case it will be protected through 2047. If Professor B wishes to print an unpublished letter by F. Scott Fitzgerald, who died in 1940, he should know that it will remain in copyright until 2010 (life plus seventy), unless it is published before the end of 2002 (or perhaps 2010), ${ }^{\text {is }}$ whereupon, again, its copyright will be extended through 2047.

On New Year's Day 2003, therefore, the public domain in the United States will claim a vast amount of unpublished material. Scholars should be alert to this date both because it will be significant for the public domain and for scholarship and because scholars who cannot wait

Joyce's writings entered the public domain in the U.K. in 1992 (when the copyright term there was still author's life plus 50 years), but were restored to copyright under the 1996 legislation.

'S See Robert Spoo, "Injuries, Remedies, Moral Rights, and the Public Domain," Introduction to "Joyce and the Law," a special issue of the James Joyce Quarterly (forthcoming); Robert Spoo, Note, "Copyright Protectionism and Its Discontents: The Case of James Joyce's Ulysses in America," 108 Yale Law Journal CVII (1998), p. 633, discussing the illusory American copyright in the 1922 edjtion of Ubsses and the consequences for scholarship and general readers; see also Warwick Gould, "Predators and Editors: Yeats in the Pre- and Post-Copyright Era," in Textual Monopolies: Literary Copyright and the Public Domain, ed. Patrick Parrinder and Warren Chernaik, Office for Humanities Communication Publication, VII (1997), pp. 69, 74-80, documenting the significant sales in the United Kingdom of inexpensive editions of W.B. Yeats's poerns following the expiration of Yeats's U.K. copyrights in 1990.

1317 U.S.C. \& 303.

It Britain's 1988 copyright law provides that works remaining unpublished after the author's death and until 1 August 1989 enjoy statutory copyright protection for fifty years from 1 January 1990 or until 31 December 2039 (CDPA, Sched. 1, para. 12[4]). For unpublished works affected by the increase of copyright terms under the European Union directive, copyrights were extended a further twenty years.

is The text of $\$ 303$ of the 1976 Copyright Act seems to allow for both interpretations. In a phone conversation (Nov. 27, 2000), the Copyright Office's Public Information Office agreed that the provision is ambiguous in this respect. At least one court has suggested that, even in the case of an author who died in 1966, publication of an unpublished work created before 1978 would have to occur before the end of 2002 in order for the work to continue to enjoy statutory copyright for the extended period provided by 303. See Batjac Prods. Inc. v. Goodtimes Home Video Corp, 160 F.3d 1223,1226 n. 3 (9th 1998). This judicial observation was not a holding, however, and therefore has limited legal authority. 
until 2003 have a valuable bargaining tool in dealing with authors' estates: imminent copyright expiration gives estates an incentive to grant permissions that they might otherwise withhold. Since estates affected by Section 303 will have no means of preventing dissemination in the United States after 2002, they may as well settle for authorized publication now and then retain copyright control, subject to fair use, until 2047 . Some scholars may find a pleasant irony in this rare alignment of the interests of researchers and estates. ${ }^{16}$

As for copyrights in anonymous or pseudonymous unpublished works, these endure for one hundred twenty years from the year they were created ${ }^{17}$ or, as the Copyright Act phrases it, "fixed in a tangible medium of expression." 18 When the date of a document's creation is uncertain, it is up to the scholar to "determine[] on the basis of internal or external evidence that the manuscript is at least [one hundred twenty] years old." ${ }^{19}$ In the case of a work written over a period of time or in variant versions-and thus "fixed" in multiple forms-the Copyright Act states that the portion of the work "that has been fixed at any particular time constitutes the work as of that time," and that "each version constitutes a separate work."20 "Thus," the legislative history concludes, "a scholar or other user, in attempting to determine whether a particular work is in the public domain, needs to look no further than the particular version he wishes to use." ${ }^{21}$ Although this reasoning places the burden of establishing fixation and copyright status upon the scholar, the skills needed to satisfy that burden are ones that fall within the scholar's traditional expertise.

Suppose Professor A has researched the matter and concluded to her satisfaction that the unpublished document from which she wishes to quote is in the public domain. If so, Professor A, or anyone else, may reproduce (in whole or in part), adapt, distribute, publicly perform, or publicly display the work without seeking permission from any copyright owner, because the private monopoly that once existed has expired, and the work has reverted to the public. My use of the word "reverted" is somewhat provocative because it suggests that the public retains an equitable interest in authors' works from the moment they are created and that this interest is merely suspended for the duration of copyright, so that authors may reap the rewards of creativity and, by extension, have an incentive to create in the first place. This, after all, is the utilitarian rationale for copyright in the Anglo-American legal system: the author is given a limited monopoly, or "headstart," 22 as an incentive to create, and the public receives two benefits over time: qualified access (as readers) to the published work during the

\footnotetext{
${ }^{16}$ The extension-upon-publication provision of $\$ 303$ of the Copyright Act is an excellent example of the "quid pro quo" that copyright law negotiates with authors.

${ }^{17} 17$ U.S.C. $\$ 302(c)$.

18 Id. $\$ \S 101 ; 102(\mathrm{a})$.

${ }^{19}$ H.R. Rep. No. 94-473, at 137, reprinted in 1976 U.S.C.C.A.N. 5659, 5753. This legislative history of the 1976 Act is often important for determining congressional intent. The passage cited above originally stated that the term for unpublished anonymous and pseudonymous works was one hundred years. That term was amended by the Sonny Bono Act to one hundred twenty years. Hence the bracketed substitution in the passage as quoted.

20 17 U.S.C. $\S$ !01 (defining "creation" of a work).

21 H.R. Rep. No. 94-473, at 137, reprinted in 1976 U.S.C.C.A.N. 5659, 5753.

22 See Benjamin Kaplan, An Unhurried View of Copyright (Columbia University Press, 1967), p. 75: "The headstart conferred (which is the encouragement given, the inducement held out) should be moderate in all its dimensions. Magnify the headstart and you may conceivably run the risk of attracting too much of the nation's energy into the copyright-protected sectors of the economy." Kaplan's book, although inevitably dated in certain respects, remains a thoughtful, eloquent treatment of the purposes and implications of copyright law.
} 
copyright period, along with a privilege to quote sparingly (as fair users) from the work's expressive content; and unqualified access (as readers or users) to the work's expressive content when the copyright expires.

Put another way, copyright is meant to lay the economic bait that will lure authors out of silence and inactivity, get them to exert themselves creatively, and, ideally, to publish the results of their exertions. ${ }^{23}$ In return for so bestirring themselves, authors receive a statebacked monopoly, an enforceable right that is formidable and lengthy enough to serve as a palpable reward, but rendered socially tolerable by means of a time limit and certain exceptions that favor users of works. This is the quid pro quo that copyright law brokers between the public and the individual talent.

This pragmatic rationale is rendered more complicated, and not a little incoherent, when applied to unpublished documents such as personal letters or private journals. These artifacts, in many cases, were never intended for publication, so the legislative bargain struck between the author and the public-a limited monopoly in exchange for cultural enrichment-seems inapplicable to such writings. Nevertheless, Congress, in 1976, chose to abolish perpetual common-law rights in unpublished works and to replace these rights with this statutory scheme of copyright terms. Therefore, scholars may rely on the Copyright Act in determining copyright or public-domain status of private unpublished documents. The difficult fit between copyright rationale and private documents, however, resurfaces in the doctrine of fair use as applied to unpublished works.

If Professor B has concluded to his satisfaction that a certain unpublished letter is in the public domain, it is unlikely that obstacles will remain to his reproducing it-unless a copyright claimant suddenly rises up and threatens to bar the way. Of course, Professor B may still have to get permission to photocopy the letter from the archive that holds it, and in rare instances an archive will even request that a scholar write it for permission to quote from a document. Strictly speaking, an archive, unless it is the copyright owner or his agent (or under the kind of contractual obligation mentioned earlier), has no business granting or withholding permission to quote a document in its collections, for the archive's ownership rights extend only to the physical document (and so to such "access" matters as photocopying documents and getting credit for owning them). It would be unfortunate for scholarship if archives insisted on arrogating to themselves incidents of ownership properly belonging to copyright holders. It would be a somewhat different matter, however, if the archive genuinely disagreed with a scholar's assessment of a work as public-domain. In that case, the scholar might, as a practical matter, be compelled to demonstrate the cogency of his assessment. But this is a

\footnotetext{
${ }^{23}$ How far this incentive model goes toward explaining the creative activity of writers like James Joyce, Virginia Woolf, and W.C. Williams-to take a few energetic souls at random-is an interesting question. Possibly, copyright statutes have little bearing on the self-propelled genius, except in the aftermath of publication when enforcement of rights may be needed. Certainly the knowledge that Ulysses would be unprotected by copyright in the United States (the largest market for his work) did not prevent Joyce from completing his modern epic and releasing it to the public. He did have assurances, however, that the work would be protected in France and other parts of Europe. See Spoo, Note, Copyright Protectionism and Its Discontents: The Case of James Joyce's Ulysses in America, supra note 12, passim.
} 
rare eventuality, not a typical one. ${ }^{24}$

However, if Professor B has decided that the letter he wants to use is still in copyright, the surest way for him to insulate himself from legal vexations, obviously, is to get permission from the copyright owner. But this is not always so easy. Some estates-such as those of H.D. and Ezra Pound-are supportive of scholarship and rarely object to reasonable quotation or to requests to print extracts from authors' writings. Others-such as those of James Joyce, T.S. Eliot, and Marianne Moore-have shown themselves to be wary of scholarship or insensitive to the fact that many of the costs of scholarly publication are borne by authors themselves. Accordingly they are difficult in the matter of permissions. These estates create what lawand-economics scholars call high "transaction costs." 25

Scholars should therefore be familiar with the doctrine of fair use-that is, the privilege to quote from copyrighted work without permission of the copyright owner, by those engaged in criticism, comment, teaching, scholarship, and similar activities. Neither Congress nor the courts have quantified fair use, even though some estates and publishers try to set precise word limits to the privilege. The statute requires a flexible balancing of four non-exclusive factors: the purpose and character of the use; the nature of the copyrighted work; the amount and substantiality of the use (qualitative or quantitative) in relation to the copyrighted work as a whole; and the likely commercial impact of the use on the potential market for or value of the copyrighted work. ${ }^{26}$

Given such a flexible test and the fact-intensive nature of many copyright disputes, it is hard to predict where a court will draw the line between fair use and infringement. In one famous case, the Supreme Court found that the quoting of three hundred words from a two hundred thousand word manuscript constituted infringement, because the nature of the copyrighted work-unpublished memoirs-favored the copyright owner, and the portion quoted, although quantitatively minuscule, was qualitatively the "heart" of the copyrighted work. ${ }^{27}$ More recently, the Fourth Circuit held that a defendant's copying of the entire manuscript of an unpublished novel for archival and scholarly purposes was a fair use, as were substantial quotations and paraphrases of the novel in a paper that she delivered at a scholarly symposium. ${ }^{2 y}$ Less encouragingly, the court added that if the identical paper were

\footnotetext{
27 Typically, if an archive has any doubts about the public-domain status of an item in its collections, it will provide a photocopy of the item along with a disclaimer of responsibility for the scholar's use of it and an admonition to seek permission from any possible copyright owner.

${ }^{25}$ Richard A. Posner, Law and Literature: A Misunderstood Relation (Harvard University Press, 1988), p. 348: “The costs of finding and negotiating with each copyright owner might have reduced Shakespeare's output, or changed (for the worse-else presumably he would have made the change on his own) his method of composition. "; see also Wendy J. Gordon, "Fair Use as Market Failure-A Structural and Economic Analysis of the Betamax Case and its Predecessors, " Columbia Law Review LXXXI (1982), p. 1600, describing fair use as a method for overcoming the transaction costs imposed by copyright ownership, and for preventing market failure-that is, the failure of either party to benefit from the copyrighted work); William M. Landes \& Richard A. Posner, “An Economic Analysis of Copyright Law," Journal of Legal Studies XVII (1989), p. 325, discussing transaction costs incurred by authors seeking to use the copyrighted works of others.

26 17 U.S.C. \& $107(1)-(4)$.

${ }^{27}$ Harper \& Row Publishers, Inc. v. Nation Enters., 471 U.S. 539, at 565 (1985).

2d Sundeman v. SeaJay Soc., Inc., 142 F.3d 194 (4 $4^{\text {th }}$ Cir. 1998). The disputed work in this case was an unpublished novel written by Marjorie Rawlings, author of The Yearling.
} 
to be published, fair use might not apply. ${ }^{29}$

Certain points regarding fair use and related exemptions are particularly important for archive-going scholars: (1) the amount of permissible quotation is not precisely fixed by copyright law, but varies from case to case; (2) scholarly quotation of copyrighted works is more favored by the law than some other kinds of uses; (3) the Copyright Act expressly extends the fair use privilege to both published and unpublished works, ${ }^{30}$ although for various reasons courts have often been more reluctant to find fair use when unpublished material is quoted; ${ }^{31}$ (4) transformative uses-uses, that is, that do not simply copy protected material but deploy it in new contexts or forms (such as critical commentary), and so pose a limited threat of "market substitution"-are more likely to be fair uses; ${ }^{32}$ and the facts and ideas contained in copyrighted works are unprotected and may be freely used by scholars, ${ }^{33}$ but close paraphrase of the author's particular wording risks crossing over into infringement. ${ }^{34}$

Finally (although this advice is probably better offered to authors' estates), in archival research, as in all matters, the law is but one tool for resolving disputes. Much of the social coherence that we experience in our lives is the product of "order without law" (to borrow a phrase from the legal scholar Robert Ellickson) ${ }^{35}$-the sane, informal folkways of compromise and restraint that we engage in every day, mostly unaware. Courts and lawsuits are a deviation from this norm of quiet, non-adversarial resolution of disputes. As Abraham

${ }^{29}$ Id. at 201, approving the lower court's finding that the scholar "understood that the paper would not be published unless the publisher first obtained the permission of the copyright holder. . . ."

36 17 U.S.C. § 107: "The fact that a work is unpublished shall not by itself bar a finding of fair use if such finding is made upon consideration of all the above factors."

"See, for example, Harper \& Row, 47I U.S. at 564: "[T] unpublished works."

32 See Campbell v. Acuff-Rose Music, Inc., 510 U.S. 569, 579 (1994), holding that one factor in determining fair use "is whether the new work merely 'supersede[s] the objects' of the original creation, or instead adds something new, with a further purpose or different character, altering the first with new expression, meaning, or message; it asks, in other words, whether and to what extent the new work is 'transformative'" Sundeman, 142 F.3d at 202, finding a scholar's substantial quotation and paraphrase of an unpublished novel in a conference paper to be "transformative"; see also Pierre Leval, Toward a Fair Use Standard, 103 Harvard Law Review CII (1990), pp. 1105, 1111, arguing that a fair use should be "transformative" of copied expression.

The Campbell Court held that the rap group, 2 Live Crew, had exercised fair use in parodying Roy Orbison's song, "Oh, Pretty Woman," despite the commercial nature of their use (in CDs, records, and tapes). Not all parody defenses have succeeded. In one controversial case, the author of a revisionary novel, The Wind Done Gone, argued, when sued for infringement by the Margaret Mitchell Trust, that she had intended her substantial borrowings of character, plot, and verbatim text to serve as historico-literary parody of the novel Gone With the Wind. The federal district court acknowledged, with respect to the first fair-use factor, that portions of The Wind Done Gone were parodic and therefore transformative. Nevertheless, in issuing a preliminary injunction, the court found, on the second factor, that the substantiality, both quantitative and qualitative, of the copying tipped the fair-use scales against the defendant. Suntrust Bank v. Houghton Miffin Co., Civ. A. No. 1:101-CV-701-CAP, 2001 WL 402351 (N.D. Ga. Apr. 20, 2001). In a further development, however, the Eleventh Circuit reversed the district court's entry of a preliminary injunction as an unlawful prior restraint in violation of the First Amendment. Suntrust Bank v. Houghton Miffin Co., D.C. Docket No. 01-00701-CV-CAP-1 (1 th Cir. May 25, 2001). At the very least, the Suntrust case implicitly raises the question of whether the parody or transformative-use defense has much vitality outside of cases involving relatively short works, such as song lyrics.

${ }^{3} 17$ U.S.C. \$ 102(b): "In no case does copyright protection . . . extend to any idea . . or discovery, regardless of the form in which it is described, explained, illustrated, or embodied. . ."

${ }^{34}$ See Salinger v. Random House, Inc., 811 F.2d 90 (2d Cir. 1987).

${ }^{35}$ See Robert C. Ellickson, Order Without Law (Harvard University Press, 1991). 
Lincoln advised his fellow lawyers: "Discourage litigation. Persuade your neighbors to compromise whenever you can. Point out to them how the nominal winner is often a real loser-in fees, and expenses, and waste of time. As a peace-maker the lawyer has a superior opertunity [sic] of being a good man. There will still be business enough." 36

36 Abraham Lincoln, "Notes on the Practice of Law" (ca. I850), in The Portable Abraham Lincoln, ed. Andrew Delbanco (Viking, 1992), pp. 33, 34 